\title{
MOTIVASI SEBAGAI PEMEDIASI PENGARUH KOMITMEN DAN LINGKUNGAN KERJA PADA KEPUASAN KERJA
}

\author{
Kustiadi Basuki ${ }^{1)}$ \\ Program Studi ManajemenFakultas Ekonomi dan Bisnis \\ Universitas 17 Agustus 1945 Jakarta \\ kustiadibasuki@yahoo.com \\ Maesaroh $^{1)}$ \\ Program Studi ManajemenFakultas Ekonomi dan Bisnis \\ Universitas 17 Agustus 1945 Jakarta \\ meymoslem@rocketmail.com
}

\begin{abstract}
This study is about "Effects of Commitment and Work Environment on Job Satisfaction With Motivation As an intervening variable in the Hospital Pharmacy Group Partners. Dependent variable in this study is the Job Satisfaction, Intervening variable is the Motivation, And independent variables are Commitment and Work Environment.

The number of respondent's surveyed population in the Hospital Pharmacy Group Partners is 90 employees, but it is taken into the study respondents were 73 employees. The sampling method is a sample random sampling, is sampling technique is done randomly so that each case or element in the population has an equal chance to be selected as the study sample.

The study was conducted with several stages. The first stage is to explore the theory of literature or by descriptive statistics and data collection of the researched object. The second stage is to test the feasibility of using the data to test data validity and reliability testing. The third stage is the stage of hypothesis testing using the t test and F test to test the hypothesis either partially or simultaneously. Furthermore, theadjusted coefficient of determination is calculated as well as the formation of the regression equation.

The results of this study demonstrate: Commitment is not significant effect on Motivation. Work Environment is significant effect on Motivation. Commitment and Work Environment jointly is significant effect on Motivation. Commitment is not significant effect 2 on Job Satisfaction. Work Environment is significant effect on Job Satisfaction. Motivation is not significantly influence on Job Satisfaction.

Commitment, Work Environment and Motivation are significant effect on Job Satisfaction. Intervention Motivation above the influence of Commitment on Job Satisfaction can not add to the strength of the effect of Commitment on Job Satisfaction. Intervention Motivation above the influence of Work Environment on Job Satisfaction can add to the strength of the effect of Work Environment on Job Satisfaction.
\end{abstract}

Keywords: Job Satisfaction, Motivation, Commitment, Work Environment

\section{ABSTRAK}

Penelitian ini adalah tentang "Pengaruh Komitmen Dan Lingkungan Kerja Terhadap Kepuasan Kerja Dengan Motivasi Sebagai Variabel Intervening pada Apotek Rumah Sakit Mitra Group. Variabel dependen dalam penelitian ini adalah Kepuasan Kerja, Variabel Intervening adalah motivasi, Dan variabel independen Komitmen dan Lingkungaan Kerja.

Jumlah populasi responden yang diteliti di Apotek Rumah Sakit Mitra Group adalah 90 karyawan, tetapi sampel yang diambil menjadi responden penelitian adalah 73 karyawan. Teknik pengambilan sampel adalah sample random sampling, yaitu teknik pengambilan sampel yang dilakukan secara acak sehingga setiap kasus atau elemen dalam populasi memiliki kesempatan yang sama besar untuk dipilih sebagai sampel penelitian.

Penelitian dilakukan dengan beberapa tahapan. Tahap pertama adalah untuk menggali teori dari pustaka atau dengan statistik deskriptif dan pengumpulan data dari objek yang diriset. Tahapan kedua adalah uji kelayakan data dengan menggunakan uji validitas data dan uji reliabilitas. Tahapan ketiga adalah tahap pengujian hipotesis dengan menggunakan uji t dan uji $\mathrm{F}$ untuk menguji hipotesis baik secara parsial maupun simultan. Selanjutnya dihitung koefisien determinasi yang disesuaikan serta pembentukan persamaan regresi.

Hasil penelitian ini membuktikan: Komitmen tidak berpengaruh signifikan terhadap Motivasi. Lingkungan Kerja berpengaruh signifikan terhadap Motivasi. Komitmen dan Lingkungan Kerja secara bersama-sama berpengaruh signifikan terhadap Motivasi. Komitmen tidak berpengaruh signifikan terhadap Kepuasan Kerja. Lingkungan Kerja berpengaruh signifikan terhadap Kepuasan Kerja. Motivasi tidak berpengaruh 
secara signifikan terhadap Kepuasan Kerja. Komitmen, Lingkungan Kerja, dan Motivasi berpengaruh signifikan Terhadap Kepuasan Kerja. Intervensi Motivasi atas pengaruh komitmen terhadap Kepuasan Kerja dapat menambah kekuatan pengaruh dari komitmen terhadap Kepuasan Kerja. Intervensi Motivasi atas pengaruh lingkungan kerja terhadap Kepuasan kerja dapat menambah kekuatan pengaruh dari Lingkungan kerja terhadap kepuasan kerja.

Kata Kunci: Kepuasan kerja, Motivasi, Komitmen, Lingkungan kerja

\section{PENDAHULUAN}

Sumber daya manusia sebagai pelaku organisasi sangat penting peranannya dalam mencapai tujuan yang diingingkan, karena sumber daya manusia merupakan alat semua kegiatan organisasi. Sebuah organisasi yang dikelola dengan sistem manajemen yang profesional yang meliputi modal, sistem, dan prosedur yang menggunakan teknologi tinggi dan menjadikan organisasi tersebut berhasil. Keberhasilan suatu organisasi tidak terlepas dari peran karyawan yang telah memiliki rasa kepuasan kerja yang optimum. Kepuasan Kerja adalah salah satu nilai positif yang ddirasakan oleh seorang karyawan terhadap suatu pekerjaannya. Dan juga merupakan tujuan dari rangkaian manajemen sumber daya manusia dapat dilakukan dengan berbagai cara seperti pemberian pelatihan dan pendidikan, komitmen, penyediaan lingkungan kerja yang baik dan pemberian motivasi yang diterapkan oleh pimpinan perusahaan. Dalam melaksanakan pekerjaannya, karyawan mempunyai komitmen tertentu sehingga mencapai kepuasan kerja pada tingkat tertentu. Komitmen adalah sesuatu keadaan dimana seorang karyawan memihak organisasi serta tujuan-tujuan dan keinginannya untuk mempertahankan keanggotaannya dalam organisasi. Rasa aman akan suasana lingkungan kerja yang disediakan oleh pimpinan perusahaan mampu mendorong karyawan untuk lebih berdedikasi tinggi dalam menyelesaikan tugasnya baik suasana aman sebelum kerja, saat kerja maupun setelah kerja. Lingkungan kerja adalah segala sesuatu yang ada disekitar para pekerja yang dapat mempengaruhi dirinya dalam menjalankan tugas-tugas yang dibebankan. Selain itu juga aspek motivasi merupakan aspek yang turut dapat mempengaruhi kepuasan kerja karyawan karena dengan pemberian motivasi yang jelas maka karyawan akan bekerja dengan giat sehingga nantinya akan mencapai rasa kepuasan kerja. Motivasi adalah upaya untuk mendapatkan pekerjaan yang mau bekerja secara ikhlas dan bersemangat sehingga dapat mencapai tujuan perusahaan. Berdasarkan latar belakang di atas, maka penulis tertarik untuk melakukan penelitian guna menyelesaikan tugas akhir perkuliahan dengan judul: “ Pengaruh Komitmen Dan Lingkungan Kerja terhadap Kepuasan Kerja Dengan Motivasi sebagai Variabel Intervening pada Apotek Rumah Sakit Mitra Group Jakarta”.

Berdasarkan uraian diatas, maka perumusan masalah dalam penelitian ini, antara lain (1) 
Apakah ada pengaruh komitmen terhadap motivasi karyawan Apotek Rumah Sakit Mitra Group ? (2) Apakah ada pengaruh lingkungan kerja terhadap motivasi karyawan Apotek Rumah Sakit Mitra Group ? (3) Apakah ada pengaruh komitmen dan lingkungan kerja secara bersama-sama terhadap motivasi karyawan Apotek Rumah Sakit Mitra Group ? (4) Apakah ada pengaruh komitmen terhadap kepuasan kerja karyawan Apotek Rumah Sakit Mitra Group ? (5) Apakah ada pengaruh lingkungan kerja terhadap kepuasan kerja karyawan Aotek Rumah Sakit Mitra Group ? (6) Apakah ada pengaruh motivasi terhadap kepuasan kerja karyawan Apotek Rumah Sakit Mitra Group ? (7) Apakah ada pengaruh komitmen, lingkungan kerja, dan motivasi secara bersama-sama terhadap kepuasan kerja karyawan Apotek Rumah Sakit Mitra Group ? (8) Apakah intervensi motivasi mampu menambah kekuatan langsung pengaruh dari komitmen terhadap kepuasan kerja karyawan Apotek Rumah Sakit Mitra Group ? (9) Apakah intervensi motivasi mampu menambah kekuatan langsung pengaruh dari lingkungan kerja terhadap kepuasan kerja karyawan Apotek Rumah Sakit Mitra Group ?

\section{TINJAUAN PUSTAKA}

\section{A. Teori Dua Faktor Herzberg}

Teori ini dikemukakan oleh Herzberg (2007 :231). Menurut teori ini ada dua faktor yang mempengaruhi kondisi pekerjaan seseorang yaitu faktor pemuas (motivator) dan faktor kesehatan (hygiene). 3 Teori Herzberg ini melihat ada dua faktor yang mendorong karyawan termotivasi yaitu faktor internal yaitu daya dorong yang timbul dari dalam diri masing-masing individu, dan yang menjadi faktor eksternal yaitu daya dorong yang datang dari luar individu, terutama dari organisasi tempat bekerja. Adapun yang merupakan faktor motivasi internal menurut Teori Herzberg (2007 : 231) adalah : (a) Pekerjaan itu sendiri (b) Prestasi yang diraih (c) Peluang untuk maju (d) Pengakuan dari orang lain (e) Tanggung jawab. Sedangkan yang menjadi faktor motivasi eksternal menurut teori Herzberg (2007 : 231) adalah : (a) Kompensasi atau gaji (b) Kondisi kerja (c) Status (d) Supervisor (e) Hubungan antar karyawan (f) Kebijakan perusahaan. Mereka yang bersikap positif terhadap situasi kerjanya akan menunjukan komitmen kerja tinggi dan sebalikya jika mereka bersikan negatif terhadap situasi kerjanya akan menunjukan situasi kerja yang rendah. Situasi kerja yang dimaksud mencakup antara lain hubungan kerja, fasilitas kerja, iklim kerja, kebijakan pimpinan, pola kepemimpinan kerja, motivasi dan kondisi kerja.

\section{B. Komitmen dan Motivasi}

Menurut Robbins (2003 : 140) komitmen organisasi adalah merupakan perpaduan antara sikap dan perilaku. Komitmen organisasi menyangkut tiga sikap yaitu : (a) Rasa mengidentifikasi dengan tujuan organisasi (b) Rasa keterlibatan dengan 
tugas-tugas organisasi (c) Rasa kesetiaan kepada organisasi. Sedangkan menurut Hasibuan (2006 : 141) motivasi adalah sesuatu yang memulai gerakan, sesuatu yang membuat orang bertindak atau berperilaku dengan cara-cara tertentu. Selanjutnya menurut Robbins (2009 : 222) menyatakan bahwa terdapat tiga kunci utama tentang motivasi dalam perilaku organisasi yaitu :

(a) Kemauan untuk berusaha (b) Pencapaian tujuan organisasi (c) Pemenuhan kebutuhan pribadi individu organisasi. Penelitian Haryanto (2012) yang menguji pengaruh komitmen organisasi terhadap motivasi yang didukung hasil penelitian Wahyuningrum (2009) mengenai Analisis Hubungan Komitmen Organisasi dan Komitmen Profesional Terhadap Motivasi, membuktikan bahwa terdapat hubungan positif dan signifikan antara komitmen organisasi dengan motivasi. Dengan adanya komitmen organisasi pada seseorang akan menimbulkan motivasi untuk bekerja sebaik-baiknya pada suatu organisasi sebagai upaya mewujudkan tujuan bersama, sebagai konsekuensi agar komitmen tersebut dapat terwujud atau tercapai. Karena motivasi merupakan proses atau faktor yang mendorong orang untuk bertindak atau berperilaku dengan cara-cara tertentu sesuai dengan komitmennya. Berdasarkan uraian tersebut maka ditetapkan hipotesis pertama dalam penelitian ini yaitu:

H1: Komitmen berpengaruh positif dan signifikan terhadap motivasi.

\section{Lingkungan Kerja Dan Motivasi}

Menurut Nursasongko (2012: 3) lingkungan kerja adalah segala sesuatu yang ada disekitar para pekerja dan dapat mempengaruhi dirinya dalam menjalankan tugas yang dibebankannya. Sedangkan menurut Mangkunegara, (2007 : 93) motivasi adalah kondisi yang menggerakkan karyawan agar mau mencapai tujuan dari motifnya. Penelitian Noermijati (2011) yang menguji pengaruh lingkungan kerja terhadap motivasi. Populasi dalam penelitian tersebut adalah seluruh karyawan PT. Merpati Mas Kediri, dengan jumlah sampel sebanyak 65 orang. Hasil penelitian tersebut kemudian didukung oleh penelitian Gienardy (2009) dalam penelitiannya pada PT. Bank Panin Sulawesi Tengah. Hasil penelitian tersebut membuktikan bahwa terdapat hubungan positif dan signifikan antara lingkungan kerja dengan motivasi. Dengan disediakannya lingkungan kerja yang baik oleh perusahaan bagi karyawan yang bekerja dalam suatu organisasi akan memberikan kontribusi pada motivasi kerja karyawan dalam bekerja. Berdasarkan uraian tersebut maka ditetapkan hipotesis kedua dalam penelitian ini yaitu:

H2: Lingkungan kerja berpengaruh positif dan signifikan terhadap motivasi.

\section{Komitmen, Lingkungan Kerja} Terhadap Motivasi

Menurut Robbin (2003 : 140) komitmen adalah suatu keadaan dimana seorang karyawan memihak pada suatu organisasi 
tertentu dan tujuan-tujuannya, serta berniat memelihara keanggotaan dalam organisasi itu. Sedangkan menurut Nursasongko (2012 :3) lingkungan kerja adalah segala sesuatu yang ada disekitar para pekerja dan dapat mempengaruhi dirinya dalam menjalankan tugas yang dibebankannya. Sedangkan menurut Mangkunegara, (2007 : 93) motivasi adalah kondisi yang menggerakkan keryawan agar mau mencapai tujuan dari motifnya. Penelitian Kartono (2013) yang menguji pengaruh komitmen terhadap motivasi, lingkungan kerja terhadap motivasi. Populasi dalam penelitian ini adalah seluruh Dosen Perguruan Tinggi Swasta Kopertis VII Jawa Timur. Hasil penelitian tersebut membuktikan bahwa terdapat hubungan positif dan signifikan antara komitmen organisasi dengan motivasi, dan terdapat hubungan positif dan signifikan antara lingkungan kerja dengan motivasi. Dengan adanya komitmen organisasi pada seseorang akan menimbulkan motivasi untuk bekerja sebaik-baiknya pada suatu organisasi supaya mewujudkan tujuan bersama, sebagai konsekuensi agar komitmen tersebut dapat terwujud atau tercapai. Serta dengan disediakannya lingkungan kerja yang baik oleh perusahaan bagi karyawan yang bekerja dalam suatu organisasi akan memberikan kontribusi pada motivasi kerja karyawan dalam bekerja dan semakin baik penataan lingkungan kerja maka akan semakin baik pula motivasi karyawan. Berdasarkan uraian tersebut maka ditetapkan hipotesis ketiga dalam penelitian ini yaitu:

H3: Komitmen dan lingkungan kerja secara bersama-sama berpengaruh positif dan signifikan terhadap motivasi.

\section{E. Komitmen Dan Kepuasan Kerja}

Menurut Robbins dan Judge (2008 : 100) komitmen organisasi dapat didefinisikan sebagai : (a) Sebuah kepercayaan dan penerimaan tujuan-tujuan dan nilai-nilai dari organisasi (b) Sebuah kemauan untuk menggunakan usaha yang sungguh-sungguh guna kepentingan organisasi (c) Sebuah keinginan untk memelihara keanggotaan dalam organisasi. Sedangkan menurut Robbins (2008 : 107) kepuasan kerja adalah suatu sikap umum terhadap pekerjaan seseorang sebagai perbedaan antara banyaknya ganjaran yang diterima karyawan dan banyaknya yang diyakini yang seharusnya diterima. Penelitian Cahyono dan Ghozali (2001) dalam penelitiannya hubungan timbal balik antara kepuasan kerja dengan komitmen organisasi. Dengan menggunakan teknik Structural Equation Modeling dalam membangun model teoritis dan menganalisis data dihasilkan kesimpulan bahwa kepuasan kerja berpengaruh negatif terhadap komitmen organisasi dan komitmen organisasi berpengaruh positif terhadap kepuasan kerja akan tetapi hubungan timbal balik tersebut tidak signifikan. Penelitian Trisnaningsih (2002) menunjukkan bahwa komitmen organisasi mempunyai pengaruh signifikan 
terhadap kepuasan kerja. Hasil penelitian tersebut kemudian didukung oleh penelitian Bongso dan Prawoto (2005) dalam penelitiannya pada Kantor Akuntan Publik I Semarang mengenai Analisis Hubungan Tipe Budaya dan Komitmen Organisasi Dengan Kepuasan Kerja Akuntan menunjukkan bahwa terdapat hubungan positif dan signifikan antara komitmen organisasi dengan kepuasan kerja. Dengan menunjukkan komitmen terhadap organisasi yang dijalani maka karyawan mengharapkan adanya pengakuan sebagai karyawan oleh organisasi dan masyarakat. Pengakuan sebagai karyawan oleh organisasi dan masyarakat akan menimbulkan perasaan bangga dan mendorong kepuasan kerja pada tingkat tertentu. Berdasarkan uraian tersebut maka ditetapkan hipotesis keempat dalam penelitian ini yaitu:

H4: Komitmen berpengaruh positif dan signifikan terhadap kepuasan kerja.

\section{F. Lingkungan Kerja Dan Kepuasan Kerja}

Menurut Sedarmayanti (2009 : 21) lingkungan kerja adalah keseluruhan alat perkakas dan bahan yang dihadapi, lingkungan sekitarnya dimana seseorang bekerja, metode kerjanya,serta pengaturan kerjanya baik sebagai perseorangan maupun sebagai kelompok. Sedangkan menurut Robbins (2011 : 114) kepuasan kerja adalah sebagai perasaan positif tentang pekerjaan sebagai hasil evaluasi dari karakteristiknya.
Penelitian Riansari (2012) yang menguji pengaruh lingkungan kerja terhadap kepuasan kerja. Populasi dalam penelitian ini seluruh karyawan PT. Bank BTPN, Cabang Malang. Dengan jumlah sampel 68 orang. Hasil penelitian tersebut kemudian didukung oleh penelitian Handaru (2013) dalam penelitiannya pada Rumah Sakit " $X$ " mengenai pengaruh lingkungan kerja terhadap kepuasan kerja. Hasil penelitian tersebut membuktikan bahwa terdapat hubungan yang positif dan signifikan antara lingkungan kerja terhadap kepuasan kerja. Dengan disediakan lingkungan kerja yang baik akan membuat karyawan berusaha melakukan aktivitas mereka dengan kemampuan yang mereka miliki agar dapat mencapai kepuasan kerja yang diinginkan. Dalam melaksanakan tugas dan pekerjaannya karyawan menginginkan lingkungan kerja yang baik agar dapat melaksanakan tugasnya dengan baik, sehingga nantinya akan mencapai rasa kepusan kerja pada tingkat tertentu. Karyawan yang memiliki rasa kepuasan kerja tinggi mengalami perasaan positif ketika mereka berpikir tentang tugas mereka atau mengambil bagian dalam mengambil aktivitas pekerjaan mereka. Berdasarkan uraian tersebut maka ditetapkan hipotesis kelima 5 dalam penelitian ini yaitu:

H5: Lingkungan kerja berpengaruh positif dan signifikan terhadap kepuasan kerja.

\section{G. Motivasi Dan Kepuasan Kerja}


Menurut Robbins dan Judge (2011 : 238) motivasi adalah proses yang memperhitungkan intensitas, arah dan ketekunan usaha individu terhadap pencapaian tujuan. Sedangkan menurut Mangkunegara, (2007 : 117) kepuasan kerja adalah perasaan yang menyokong diri karyawan yang berhubungan dengan pekerjaannya maupun dengan kondisi kerjanya. Penelitian Zahrotul M (2011) yang menguji pengaruh motivasi terhadap kepuasan kerja. Populasi dalam penelitian tersebut seluruh karyawan PT. Putra Kencana Cabang Malang, dengan jumlah sampel sebanyak 61 orang. Hasil penelitian tersebut kemudian didukung oleh Setiawati (2010) yang menguji pengaruh motivasi terhadap kepuasan kerja, populasi dalam penelitian tersebut seluruh karyawan Hotel "X" Food and Beverage, Surabaya. Hasil penelitian tersebut membuktikan bahwa terdapat hubungan positif dan signifikan antara motivasi dengan kepuasan kerja. Dengan motivasi yang tinggi maka akan menghasilkan kepuasan kerja yang tinggi. Motivasi yang diberikan perusahaan baik secara internal maupun eksternal kepada karyawan, maka akan membuat karyawan tersebut berusaha bekerja dengan kemampuan yang mereka miliki agar apat mencapai kepuasan kerja yang diinginkan. Sehingga motivasi akan berpengaruh terhadap kepuasan kerja. Berdasarkan uraian tersebut maka ditetapkan hipotesis keenam dalam penelitian ini yaitu:
H6: Motivasi berpengaruh positif dan signifikan terhadap kepuasan kerja.

\section{H. Komitmen, Lingkungan Kerja, Motivasi Terhadap Kepuasan Kerja}

Menurut Sopiah (2008 : 155) komitmen organisasi adalah derajat yang mana karyawan percaya dan menerima tujuantujuan organisasi dan akan tetap tinggal atau tidak akan meninggalkan organisasi. Sedangkan menurut Rahayu (2009 : 15) lingkungan kerja merupakan suatu situasi dimana para karyawan tersebut bekerja. Sedangkan menurut Sardiman (2006 : 73) motivasi merupakan daya penggerak dari dalam diri karyawan untuk melakukan kegiatan untuk mencapai tujuan. Kepuasan kerja adalah evaluasi seseorang atas pekerjaannya dan konteks pekerjaan yang merupakan penilaian terhadap karakteristik pekerjaan, lingkungan kerja dan pengalaman emosional dipekerjaan yang dirasakan. Penelitian Lestari (2010) yang menguji pengaruh komitmen organiasai terhadap kepuasan kerja. Hasil penelitian tersebut kemudian didukung oleh Tarwan (2011) yang menguji pengaruh komitmen organisasi terhadap kepuasan kerja. Hasil penelitian selanjutnya mengenai pengaruh lingkungan kerja terhadap kepuasan kerja yang dikemukakan oleh Yunanda (2009). Hasil penelitian selanjutnya oleh Sudaryanto (2007) yang menguji pengaruh lingkungan kerja terhadap kepuasan kerja. Hasil penelitian selanjutnya mengenai pengaruh 
motivasi terhadap kepuasan kerja oleh Sarifa dan Agustina (2008). Hasil penelitian tersebut membuktikan bahwa terdapat hubungan yang positif dan signifikan antara komitmen terhadap kepuasan kerja, lingkungan kerja terhadap kepuasan kerja dan motivasi terhadap kepuasan kerja. Berdasarkan uraian tersebut maka ditetapkan hiotesis ketujuh dalam penelitian ini yaitu:

H7: Komitmen, lingkungan kerja dan motivasi secara simultan berpengaruh positif dan signifikan terhadap kepuasan kerja.

\section{Intervensi Motivasi Atas Pengaruh} Komitmen Terhadap Kepuasan Kerja

Menurut Newstrom (2011 : 109) motivasi kerja adalah hasil dari kumpulan kekuatan internal dan eksternal yang menyebabkan karyawan memilih jalan bertindak yang sesuai dan menggunakan perilaku tertentu. Sedangkan menurut Robbins dan Judge (2008 : 100) komitmen adalah tingkat sampai sejauh mana seorang karyawan memihak sebuah organisasi serta tujuantujuan dan keinginannya untuk mempertahankan keanggotaan dalam organisasi tersebut. Sedangkan menurut Colquitt, et, al (2011 : 105) kepuasan kerja adalah tingkat perasaan menyenangkan yang diperoleh dari penilaian seseorang atau pengalaman kerja. Penelitian Trisnaningsih (2002) dalam penelitiannya menunjukkan bahwa komitmen organisasi mempunyai pengaruh secara tidak langsung melalui variabel intervening motivasi terhadap kepuasan kerja. Dalam penelitian diketahui bahwa pengaruh langsung variabel komitmen organisasi terhadap kepuasan kerja lebih besar dibandingkan dengan pengaruh tidak langsung variabel komitmen organisasi terhadap kepuasan kerja dengan melalui variabel intervening motivasi. Berdasarkan uraian tersebut maka hipotesis kedelapan dalam penelitian ini yaitu:

H8: Intervensi motivasi dapat menambah kekuatan pengaruh langsung dari komitmen terhaap kepuasan kerja.

\section{J. Intervensi Motivasi Atas Pengaruh} Lingkungan Kerja Terhadap Kepuasan

\section{Kerja}

Menurut Kreitner dan Kinicki (2010 : 212) motivasi berarti proses psikologis yang membangkitkan, mengarahkan dan ketekunan dalam melakukan tindakan secara sukarela yang diarahkan pada pencapaian tujuan. Sedangkan menurut Rivai (2006 : 105) lingkungan kerja adalah keseluruhan sarana dan prasarana yang ada disekitar karyawan yang sedang melakukan pekerjaan itu sendiri. Sedangkan menurut Shane dan Glinow (2010 : 108) kepuasan kerja adalah evaluasi seseorang atas pekerjaannya dan konteks pekerjaan Penelitian Riani (2013) dalam penelitiannya menunjukkan bahwa motivasi dapat meningkatkan kepuasan kerja karyawan di RSUD Pandan Arang Boyolali. Hasil penelitian ini menunjukkan bahwa lingkungan kerja dan interaksi sosial terhadap kepuasan kerja karyawan RSUD 
Pandan Arang Boyolali dengan motivasi sebagai variabel intervening adalah berpengaruh signifikan. Dari uraian tersebut maka ditetapkan hipotesis kesembilan pada penelitian ini yaitu: H9: Intervensi motivasi dapat menambah kekuatan pengaruh langsung dari lingkungan kerja terhadap kepuasan kerja.

\section{METODE PENELITIAN}

Penelitian ini termasuk penelitian menggunakan pendekatan kuantitatif dengan alat utama kuesioner yang diajukan kepada karyawan Apotek Rumah Sakit Mitra Group dengan menggunakan analisis deskriptif, pengujian kualitas data, pengujian hipotesis dan analisis regresi
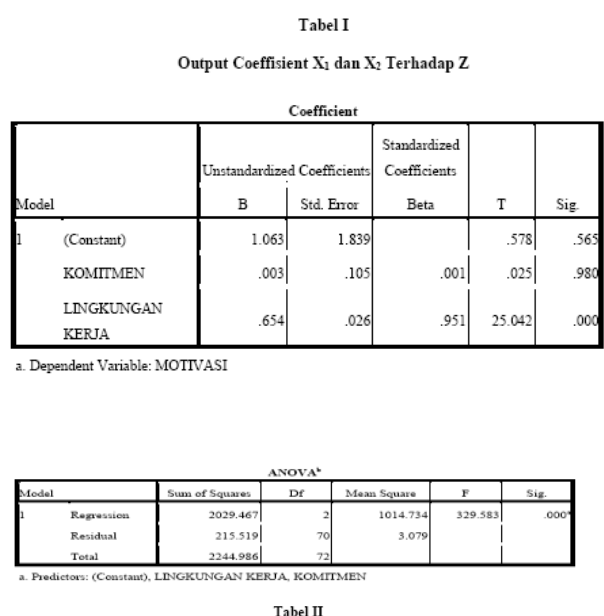

Output Coeffisient $\mathrm{X}_{1}, \mathrm{X}_{2}$ Dan $\mathrm{Z}$ Terhadap $\mathrm{Y}$

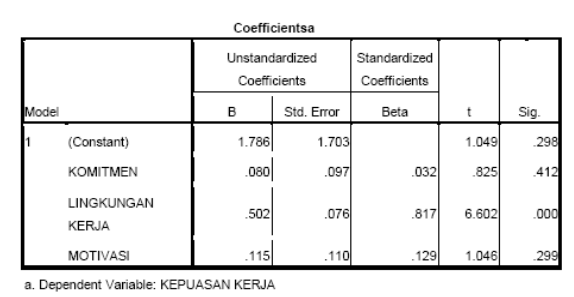

berganda. Analisis item dilakukan dengan menggunakan SPSS 16. Populasi dalam penelitian ini adalah seluruh staff karyawan divisi finance, administrasi, dan penjualan sebanyak 90 karyawan. Jumlah sampel yang diperoleh dengan rumus slovin sebanyak 73 responden.Teknik pengambilan sampel dalam penelitian ini menggunakan teknik disportionate stratified random sampling dikarenakan populasi dijadikan sampel tidak homogeny dan berstrata secara proporsional.

\section{HASIL DAN PEMBAHASAN}

Hasil penelitian ini di rangkum secara keseluruhan dalam tabel sebagai berikut :

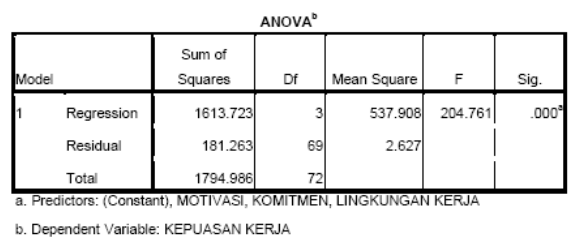

\section{Pembuktian Hipotesis Pertama}

H1: Komitmen berpengaruh secara positif dan signifikan terhadap motivasi. Berdasarkan tabel I coefficient pada kolom sig, Hasil pengujian secara parsial diperoleh bahwa signifikansi sig 0,980 >0,05. Hasil t hitung lebih kecil dari $\mathrm{t}$ tabel, yaitu $\mathrm{t}$ hitung $0,025<\mathrm{t}$ tabel 2,00. Hal ini menunjukkan bahwa secara parsial variabel komitmen terhadap motivasi tidak berpengaruh signifikan, sehingga H1 ditolak. Dengan adanya komitmen organisasi pada seseorang akan menimbulkan motivasi untuk bekerja sebaik-baiknya pada suatu organisasi 
sebagai upaya mewujudkan tujuan bersama, sebagai konsekuensi agar komitmen tersebut dapat terwujud atau tercapai. Karena motivasi merupakan proses atau faktor yang mendorong orang untuk bertindak atau berperilaku dengan cara-cara tertentu sesuai dengan. Hasil penelitian ini juga dapat dibuktikan secara konsistensi dari penelitian terdahulu yang dilakukan oleh Haryanto (2012).

\section{Pembuktian Hipotesis Kedua}

H2: Lingkungan kerja berpengaruh secara positif dan signifikan terhadap motivasi.

Berdasarkan tabel II coefficient pada kolom sig, Hasil pengujian secara parsial diperoleh bahwa signifikansi sig $0,000<0,05$. Hasil t hitung lebih besar dari t tabel, yaitu t hitung $25.042>t$ tabel 2,00. Hal ini menunjukkan bahwa secara parsial variabel lingkungan kerja terhadap motivasi berpengaruh signifikan, sehingga $\mathrm{H} 2$ diterima. Lingkungan kerja sangat berpengaruh terhadap motivasi. Apabila perusahaan menyediakan lingkungan kerja yang baik bagi karyawan yang bekerja dalam suatu organisasi maka akan memberikan kontribusi pada motivasi kerja karyawan dalam bekerja.

\section{Pembuktian Hipotesis Ketiga}

H3: Komitmen dan lingkungan kerja bersama-sama berpengaruh secara positif dan signifikan terhadap motivasi. Berdasarkan tabel I coefficient pada kolom sig, Hasil pengujian secara simultan diperoleh bahwa signifikansi sig 0,000 < 0,05 dan hasil $\mathrm{F}$ hitung sebesar $329.583>\mathrm{F}$ tabel sebesar 3,15. Hal ini menunjukkan bahwa secara simultan variabel komitmen dan lingkungan kerja terhadap motivasi berpengaruh signifikan, sehingga $\mathrm{H} 3$ diterima. Seperti dijelaskan sebelumnya bahwa motivasi sangat dipengaruhi oleh komitmen dan lingkungan kerja. Keduanya saling berhubungan satu sama lain. Apabila seorang karyawan mempunyai komitmen yang tinggi terhadap organisasinya dan cara pimpinan perusahaan menyediakan lingkungan kerja yang baik maka karyawan akan termotivasi untuk melakukan pekerjaan dengan baik. Hasil penelitian ini juga dapat dibuktikan secara konsistensi dari penelitian terdahulu yang dilakukan oleh Kartono (2013).

\section{Pembuktian Hipotesis Keempat}

H4: Komitmen berpengaruh secara positif dan signifikan terhadap kepuasan kerja.

Berdasarkan tabel II coefficient pada kolom sig, Hasil pengujian secara parsial diperoleh bahwa sig 0,412>0,05. Hasil t hitung 0,825 $<\mathrm{t}$ tabel 2,00. Hal ini menunjukkan bahwa secara parsial variabel komitmen terhadap kepuasan kerja tidak berpengaruh signifikan sehingga H4 ditolak. Dalam pencapaian kepuasan kerja sebenarnya komitmen merupakan faktor yang turut menunjang dalam menghasilkan kepuasan kerja, karena dengan seorang yang memiliki komitmen 
yang tinggi terhadap suatu organisasinya maka seseorang akan bekerja secara semangat sehingga nantinya akan merasakan kepuasan dalam bekerja. Tetapi dalam perusahaan Apotek ini komitmen karyawan tidak berpengaruh secara signifikan terhadap kepuasan kerja. Hasil penelitian ini juga dapat dibuktikan secara konsistensi dari penelitian terdahulu yang dilakukan oleh Cahyono dan Ghazali (2001).

\section{Pembuktian Hipotesis Kelima}

H5: Lingkungan kerja berpengaruh secara positif dan signifikan terhadap kepuasan kerja. Berdasarkan tabel II coefficient pada kolom sig, Hasil pengujian secara parsial diperoleh bahwa sig 0,000 $<0,05$. Hasil $\mathrm{t}$ hitung 6,602 > t tabel 2,00. Hal ini menunjukkan bahwa secara parsial variabel lingkungan kerja terhadap kepuasan kerja berpengaruh signifikan, sehingga H5 diterima. Apabila seorang pimpinan perusahaan menyediakan lingkungan kerja yang baik bagi karyawan, maka karyawan akan bekerja dengan sebaik-baiknya sehingga nantinya akan menimbulkan rasa kepuasan kerja bagi karyawan. Hasil penelitian ini juga dapat dibuktikan secara konsistensi dari penelitian terdahulu yang dilakukan oleh Riansari (2012).

\section{Pembuktian Hipotesis Keenam}

H6: Motivasi berpengaruh secara positif dan signifikan terhadap kepuasan kerja.

Berdasarkan tabel II coefficient pada kolom sig, Hasil pengujian secara parsial diperoleh bahwa signifikansi sig 0,299>0,05. Hasil t hitung lebih kecil dari $\mathrm{t}$ tabel, yaitu $\mathrm{t}$ hitung $1.046<\mathrm{t}$ tabel 2,00. Hal ini menunjukkan bahwa secara parsial variabel motivasi terhadap kepuasan kerja tidak berpengaruh signifikan, sehingga H6 ditolak. Motivasi merupakan faktor penting dalam pencapaian kepuasan kerja. Apabila perusahaan memberikan motivasi baik secara internal maupun eksternal maka karyawan akan semakin bersemangat dalam melakukan pekerjaannya. Tetapi motivasi karyawan Apotek Rumah Sakit Mitra Group ini tidak berpengaruh signifikan terhadap kepuasan kerja karena motivasi yang diberikan oleh perusahaan tidak bisa membuat karyawan nya merasa terpuaskan dalam bekerja. Hasil penelitian ini juga dapat dibuktikan secara konsistensi dari penelitian terdahulu yang dilakukan oleh Zahrotul M (2011).

\section{Pembuktian Hipotesis Ketujuh}

H7: Komitmen, lingkungan kerja dan motivasi secara bersama-sama berpengaruh secara positif signifikan terhadap kepuasan kerja. Berdasarkan tabel II coefficient pada kolom sig, Hasil pengujian secara simultan diperoleh bahwa signifikan sig 0,000 $<0,05$ dan hasil F hitung sebesar $204.761>$ F tabel sebesar 2.76. Hal ini menunjukkan bahwa secara simultan variabel komitmen, lingkungan kerja dan motivasi dan 
berpengaruh signifikan terhadap kepuasan kerja, sehingga H7 diterima. Seperti dijelaskan sebelumnya bahwa komitmen, lingkungan kerja dan motivasi saling berpengaruh satu sama lain dalam pencapaian kepuasan kerja. Dalam melaksanakan tugas pekerjaannya, karyawan mempunyai komitmen tertentu sehingga mencapai kepuasan kerja pada tingkat tertentu. Rasa aman akan lingkungan kerja yang disediakan pimpinann perusahaan mampu mendorong karyawan untuk lebih berdedikasi tinggi dalam menyelesaikan tugasnya baik suasana aman sebelum kerja, saat kerja maupun setelah kerja. Disisi lain, kebutuhan dari karyawan dalam memenuhi keinginannya semakin meningkat. Karyawan dengan harapan akan memperoleh upah atau gaji untuk memenuhi kebutuhan tersebut. Motivasi berperan untuk mensejajarkan kepentingan individualnya dan kepentingan organisasinya serta mengajak anggota individualnya untuk loyal terhadap perusahaan. Hasil penelitian ini juga dapat dibuktikan secara konsistensi dari penelitian terdahulu yang dilakukan oleh Lestari (2010).

\section{Pembuktian Hipotesis Kedelapan}

H8: Adanya intervensi motivasi atas pengaruh komitmen mampu menambah kekuatan langsung pengaruh dari komitmen terhadap kepuasan kerja. Pengaruh langsung dari komitmen terhadap kepuasan kerja adalah sebesar 0,032 , sedangkan pengaruh tidak langsungnya sebesar sebesar $0,001 \mathrm{x}$
$0,129=0,129$. Artinya intervensi motivasi dapat menambah kekuatan pengaruh dari komitmen terhadap kepuasan kerja. Intervensi dari motivasi mampu menambah kekuatan yang positif dalam pencapaian kepuasan kerja melalui komitmen. Karena dengan adanya komitmen yang dimiliki seorang karyawan terhadap organisasinya maka karyawan tersebut akan termotivasi untuk bekerja sebaik-baiknya. Hasil penelitian ini juga dapat dibuktikan secara konsistensi dari penelitian terdahulu yang dilakukan oleh Trisnaningsih (2002)

\section{Pembuktian Hipotesis Kesembilan}

H9: Adanya intervensi motivasi atas pengaruh lingkungan kerja terhadap kepuasan kerja mampu menambah kekuatan langsung dari lingkungan kerja terhadap kepuasan kerja. Pengaruh langsung dari lingkungan kerja terhadap kepuasan kerja adalah sebesar 0,817. Sedangkan pengaruh tidak langsungnya sebesar $0,951 \times 0,129=0,122$. Artinya intervensi motivasi dapat menambah kekuatan pengaruh dari lingkungan kerja terhadap kepuasan kerja. Intervensi dari motivasi mampu menambah kekuatan yang positif dalam pencapaian kepuasan kerja melalui lingkungan kerja. Seseorang yang bergabung dengan suatu organisasi tentunya membawa keinginan-keinginan, kebutuhan dan pengalaman masa lalu yang membentuk 
harapan kerja baginya, dan bersamasama dengan organisasinya berusaha mencapai tujuan bersama. Motivasi dapat juga meningkatkan kepuasan kerja, hal ini disebabkan karena motivasi adalah faktor penggerak yang akan mengarahkan orang tersebut melakukan suatu pekerjaan. Oleh karena itu pihak perusahaan perlu menciptakan dan memelihara lingkungan kerja yang baik, karena lingkungan kerja yang baik akan membuat karyawan bekerja lebih giat dan secara otomatis dapat meningkatkan produktifitas kerja karyawan yang juga berdampak langsung terhadap kepuasan kerja. Tingkat kepuasan kerja banyak menunjukkan kesesuainnya dengan harapan kerja yang sering merupakan motivasi kerja. Hasil penelitian ini juga dapat dibuktikan secara konsistensi dari penelitian terdahulu yang dilakukan oleh Riani (2013).

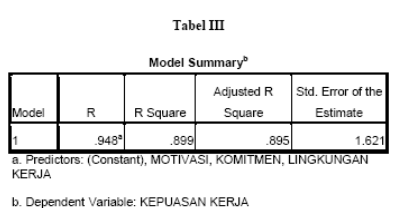

Model summary menunjukkan Koefisien Determinasi Adjusted $R$ Square sebesar 0,895 atau sebesar $89,5 \%$ yang berarti bahwa kemampuan variabel komitmen dan lingkungan kerja dalam menjelaskan motivasi serta dampaknya terhadap kepuasan kerja adalah sebesar 89,5\%, sedangkan sisa sebesar $10,5 \%$ dijelaskan oleh vaariabel lain diluar variabel penelitian ini.

\section{SIMPULAN DAN SARAN}

\section{Simpulan}

Sesuai dengan analisis data yang telah dilakukan, maka dapat ditarik kesimpulan sebagai berikut :

(a) hasil pengujian hipotesis pertama komitmen tidak mempunyai pengaruh yang signifikan terhadap motivasi. Arah pengaruh yang diberikan adalah positif atau searah. Hal ini berarti bahwa hipotesis pertama ditolak.

(b) hasil pengujian hipotesis kedua lingkungan kerja mempunyai pengaruh yang signifikan terhadap motivasi. Arah pengaruh yang diberikan adalah positif atau searah. Hal ini berarti bahwa hipotesis kedua diterima.

(c) hasil pengujian hipotesis ketiga komitmen dan lingkungan kerja secara bersama-sama berpengaruh terhadap motivasi. Arah pengaruh yang diberikan adalah positif atau searah. Hal ini berarti bahwa hipotesis ketiga diterima.

(d) hasil pengujian hipotesis keempat komitmen tidak berpengaruh secara signifikan terhadap kepuasan kerja. Hal ini berarti hipotesis keempat ditolak.

(e) Hasil pengujian hipotesis kelima lingkungan kerja berpengaruh secara signifikan terhadap kepuasan kerja. Hal ini berarti hipotesis kelima diterima.

(f) hasil pengujian hipotesis keenam ditemukan bukti empiris bahwa secara 
parsial motivasi tidak berpengaruh terhadap kepuasan kerja. Hal ini berarti hipotesis keenam ditolak.

(g) hasil pengujian hipotesis ketujuh komitmen, lingkungan kerja, dan motivasi secara bersama-sama berpengaruh signifikan terhadap kepuasan kerja. Berdasarkan pembuktian ini maka dapat disimpulkan hipotesis ketujuh diterima.

(h) hasil pengujian hipotesis kedelapan, intervensi motivasi atas pengaruh komitmen terhadap kepuasan kerja dapat menambah kekuatan beta pengaruh dari komitmen terhdap kepuasan kerja. Dengan demikian dapat disimpulkan bahwa hipotesis kedelapan diterima.

(i) hasil pengujian hipotesis kesembilan intervensi motivasi atas pengaruh lingkungan kerja terhadap kepuasan kerja dapat menambah kekuatan beta pengaruh dari lingkungan kerja terhdap kepuasan kerja. Dengan demikian dapat disimpulkan bahwa hipotesis kesembilan diterima.

\section{Saran}

Beberapa saran yang diajukan peneliti yang dapat digunakan untuk penelitian mendatang yaitu (a) variabel kepuasan kerja pencapaiannya masih harus ditingkatkan lagi sebesar $15,2 \%$. (b) variabel motivasi pencapaiannya harus ditingkatkan lagi sebesar $32,0 \%$. (c) variabel komitmen pencapaiannya harus ditingkatkan lagi sebesar 20,05\%. (d) variabel lingkungan kerja pencapaiannya harus ditingkatkan lagi sebesar 16,06\%. (e) penelitian selanjutnya diharapkan dapat memperoleh data dari sumber yang lebih lengkap dengan menambah jumlah responden. (f) penelitian selanjutnya diharapkan menambah jumlah variabel bebas dalam penelitian berikutnya, seperti budaya organisasi, kompensasi, kemampuan kerja, kepemimpinan, pendidikan, dan pelatihan kerja.

\section{DAFTAR PUSTAKA}

Bongso dan Prawoto, 2005, Analisis Hubungan Tipe Budaya dan Komitmen Organisasi Dengan Kepuasan Kerja.

Cahyono dan Ghozali, 2001, pengaruh komitmen organisasi terhadap kepuasan kerjal.

Colquitt, et, al, 2011. Organization Behavior : Improving Performance and Commitment in the Workplace. New York: The McGraw - Hill Com., Inc

Gienardy, 2009, pengaruh lingkungan kerja terhadap motivasi pada PT. Bank Panin Sulawesi Tengah.

Herzberg, F. 2007, The Manajerial Choice. PT. Salemba Empat, Jakarta.

Hasibuan, Malayu P, 2006, Manajemen Dasar, Pengertian, dan Masalah, Edisi Revisi, Bumi Aksara: Jakarta

Haryanto ,2012, pengaruh komitmen organisasi terhadap motivasi pada PT.Bank DKI Cabang Kebayoran Baru, Jakarta,

Kartono, B, 2013, pengaruh komitmen terhadap motivasi, lingkungan kerja terhadap motivasi. pada Perguruan Tinggi Swasta Kopertis VII Jawa Timur.

Kreitner dan Kinicki, 2010, Organizational Behavior, New York : McGraw-Hill.

Lestari, E, 2010 Pengaruh Komitmen Organisasi Terhadap Kepuasan Kerja. 
Mangkunegara, A.P ,2007. Manajemen Sumber Daya Manusia Perusahaan. PT. Remaja Rosdakarya, Bandung

Newstorrm, J.W, 2011, Organizational Behavior, Human Behavior at Work.

Nursasongko, G.S, 2012, The Human Resource. PT. Salemba Empat, Jakarta.

Noermijati, A.F, 2011, Pengaruh Lingkungan Kerja Terhadap Motivasi.

Rahayu, 2009, Konsep dan Aspek Lingkungan Kerja, Bandung : Alfabeta

Robbins dan Judge 2008. Perilaku Organisasi, Jakarta : Salemba Empat

-------, 2011, Organizational Behavior, New Jersey: Pearson Education.

------, 2009. Perilaku Organisasi : Organizasional Behavior, Jakarta: Salemba Empat.

Rivai, 2006, Manajemen Sumber Daya Manusia untuk Perusahaan. Jakarta : Rajagrafindo Persada

Riani, A.L (2013), Pengaruh Motivasi Terhadap Kepuasan Kerja,

Sardiman, 2006, Interaksi dan Motivasi. Jakarta : Raja Grafindo Persada

Setiawati, 2010, Pengaruh Motivasi Terhadap Kepuasan Kerja Pada Hotel ' $\mathrm{X}$ ' Food And Beverage. .

Sopiah, 2008, Perilaku Organisasi, Andi, Yogyakarta

Sudaryanto, Andik, 2007, Pengaruh Lingkungan Kerja Terhadap Kepuasan Kerja.

Sarifa dan Agustina, 2008, Analisis Pengaruh Motivasi Terhadap Kepuasan Kerja. .

Sedarmayanti, 2009. Manajemen Sumber Daya Manusia, Cetakan Pertama, Bandung : PT. Refika

Aditama

Trisnaningsih, S, 2002, Pengaruh komitmen organisasi terhadap kepuasan kerja RSUD Pandan Arang Boyolali

Tarwan, T, 2011, Analisis Pengaruh Komitmen Organisasi Terhadap Kepuasan Kerja.

Wahyuningrum, C.H, 2009, Pengaruh komitmen organisasi dan komitmen profesional terhadap motivasi,pada Kantor Akuntan Publik di Semarang.
Wursanto, 2009, Dasar-Dasar Ilmu Organisasi. Yogyakarta : Andi Yunanda, M.A, 2009, Pengaruh Lingkungan Kerja Terhadap Kepuasan Kerja.

Zahrotul, M.T, 2011, Analisis Pengaruh Motivasi Terhadap Kepuasan Kerja, 